\title{
Launching an EdD in Community College Leadership Program with Activism in Mind
}

\author{
Christine Harrington \\ New Jersey City University \\ charrington1@njcu.edu \\ John Melendez \\ New Jersey City University \\ jmelendez@njcu.edu
}

\begin{abstract}
The purpose of this article is to share an example of how an activism framework was used to design and launch a new EdD in Community College Leadership. Capper, Theoharis, and Sebastian's (2006) framework for preparing leaders for social justice along with the Carnegie Project for the Education Doctorate's (CPED) guiding principles and the American Association of Community College's ([AACC], 2018) competencies for community college leaders guided program design and implementation. Marketing and recruiting efforts aimed at identifying a talented, diverse cohort and on-boarding strategies focused on creating a safe learning environment and a sense of urgency related to social justice and equity are shared. Examples of how activism is being emphasized through coursework and plans to nurture activism through experiential learning and the dissertation are also discussed. Doctoral programs seeking to promote activism will discover an effective framework and practical examples for this work.
\end{abstract}

KEYWORDS: activism, community college leadership, social justice, equity, program launch

In 2015, New Jersey City University began the design and development of an EdD in Community College Leadership. The program reflects the university's commitment to empower diverse, underserved, and underrepresented individuals to become change agents, close achievement gaps, and respond to ever-changing, global, $21^{\text {st }}$ century opportunities and challenges. In a short period of time during the 2019 spring semester, the two full-time faculty members in the program modified the program goals and engaged in a redesign process so that the curriculum aligned with the principles shared by CPED. All course titles and descriptions were reviewed and numerous modifications and changes were made to strengthen the focus on equity, social justice, and scholarly practice, key CPED principles. For example, a course initially titled Adult Learning and the Community College Student was revised to Promoting Equity: Teaching and Supporting Adult Diverse Learners. As another example, the research course sequence now begins with a course titled The Scholarly Practitioner, changed from An Introduction to Inquiry. As Peterson (2017) notes, a tight timeline creates a sense of urgency that often leads to desired program changes.

Access, equity, and opportunity are central to the mission of community colleges. These same values were drivers in the development of the doctoral program in Community College Leadership that was launched by New Jersey City University in 2019. Developing community college leaders who are prepared to engage in activism to promote social justice and equity requires intentional program design and implementation. The goals of the
Ed.D. in Community College Leadership program are to develop community college leaders who:

- Use an evidence-based approach to decision making and leadership, with a focus on the goal of increased rates of student completion and success.

- Promote culturally responsive pedagogical and supportive practices that are grounded in theory and research.

- Engage in partnerships to champion the mission of the community college and lead various reform efforts aimed at reducing equity gaps.

- Effectively engage in strategic planning and assessment and clearly communicate vision and data to various stakeholders.

These goals served as the guidepost in the recruitment, design, and implementation stages of the program.

Strategic, intentional actions to attract a diverse cohort of doctoral students committed to social justice were employed. The program goals were also used to drive the design and implementation of the program, including determining on-boarding processes, designing the summer institute, planning and implementing a Community College Showcase conference, developing curriculum, determining experiential learning opportunities, and defining the dissertation. All elements of the program were designed with the intention to develop scholarly practitioners who have an activist agenda. Activists are leaders who champion causes by using their passion and expertise to partner
New articles in this journal are licensed under a Creative Commons Attribution 4.0 United States License. Program and is cosponsored by the University of Pittsburgh Press.

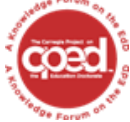

This journal is supported by the Carnegie Project on the Education Doctorate: A Knowledge Forum on the EdD (CPED) cpedinitiative.org 
with others to effect change. Activism within the community college sector is particularly important given the diverse population served.

\section{CONCEPTUAL FRAMEWORK}

Capper et al.'s (2006) framework for preparing leaders for social justice, the AACC's (2018) competencies for community college leaders, and CPED's(n.d.) guiding principles and design concepts served as a guide for program design and implementation. Capper et al.'s (2006) framework describes the qualities, knowledge, and abilities needed by educational leaders in order to effect change, and the strategies that leadership programs can employ to prepare students to be change agents. Although this framework was initially designed for K-12 leaders, it can easily be adapted for higher education. George (2017) provided an example of how this framework could be used for the purpose of program evaluation in a higher education doctoral program, describing how an institution reviewed and assessed a newly established EdD in Higher Education Administration using key concepts such as critical consciousness from Capper et al.'s (2006) framework.

Capper et al.'s (2006) framework has six key components across two dimensions. The horizontal dimension focuses on the knowledge, beliefs, and actions of school leaders and includes critical consciousness, knowledge, and skills. Critical consciousness refers to educator leaders developing an awareness and understanding of the role that power and privilege play in education and society. It also involves empowering individuals to be change agents who address inequities. Knowledge and skills refer to possessing the necessary background information and abilities to be an effective leader. Capper et al. emphasized the importance of creating an emotionally safe place for students to explore issues of social justice and equity. A safe place is one where students feel valued and respected, and as a result are comfortable sharing their thoughts and ideas with others. Although this framework provides a productive lens centered on social justice, the unique focus of this program on community college leadership required an additional framework that specifically articulated the knowledge and skills needed by community college leaders. The leadership competencies developed by the AACC (2018), therefore, served as the benchmarks for knowledge and skill development. These competencies address the numerous skill areas that community college leaders need to be effective change agents in various leadership positions and include: (1) organizational culture, (2) governance, institutional policy and legislation, (3) student success, (4) institutional leadership, (5) institutional infrastructure, (6) information and analytics, (7) advocacy and mobilizing/motivating others, (8) fundraising and relationship cultivation, (9) communications, (10) collaboration, and (11) personal traits and abilities.

The vertical dimension of Capper et al.'s (2006) framework focuses on what leader preparation programs need to do to help students develop critical consciousness, knowledge, and skills. Curriculum, pedagogy, and assessment are the components of the vertical dimension. In addition to considering all of the aspects of Capper et al.'s (2006) framework, CPED's (n.d.) guiding principles and design concepts also served as a guide during program development and implementation. For example, assisting students with developing questions aimed at discovering practitioner solutions related to equity, ethics, and social justice issues, the first guiding principle described by CPED, became an overarching focus for the program. Starting with pre-admission processes, prospective students heard empowering messages about how their actions as a leader would make a difference in the lives of community college students. Empowerment combined with skill development through coursework, experiential learning, and the dissertation will likely result in activist leaders.

\section{MARKETING AND RECRUITMENT}

From the outset, as described in the original doctoral program proposal, the program was designed to serve doctoral students from diverse career backgrounds, including full-time and part-time faculty, mid-level managers, and other education professionals aspiring for community college leadership opportunities. The program was also focused on recruiting and supporting doctoral candidates from underrepresented groups who had an activist orientation and an expressed commitment to addressing social justice and equity issues within the community college sector. As articulated by Allen, Wasicsko, and Wirtz (2018), there is a high demand for transformational leaders and our program hoped to contribute by identifying and developing these activist-oriented individuals.

To find this target audience, a communication marketing plan was developed. This plan included a variety of outreach activities including email, traditional mail, virtual information sessions, limited social media use, and information sessions held on community college campuses. The two full-time faculty members also leveraged professional networks to identify diverse community college experts and leaders to serve on an advisory board. The 18-member advisory board is comprised of community college presidents, vice presidents, mid-level administrators, state leaders, and community college researchers. To increase the likelihood of attracting diverse doctoral students, special efforts were made to conduct information sessions at community colleges in urban settings as these colleges had a more diverse faculty and staff. The advisory board played a critical role in this process as members assisted with setting up information sessions and helped spread the word about the new program. For example, a president of a local urban community college widely advertised an information session on his campus and as a result, we had over 20 faculty and administrators attend.

Emphasizing the scholarly practitioner model and the importance of developing leaders at all levels was a particularly important message during the recruitment phase. During online and in-person information sessions, faculty highlighted how the Community College Leadership program was designed to develop leaders who would act as change agents to move the needle on student success outcomes and close equity gaps. Because many prospective students may not necessarily think of themselves as leaders or activists, examples of activism in many different leadership roles and positions were shared. In addition, prospective students were informed of opportunities to develop activist skills through coursework and experiential learning opportunities. The commitment of the faculty to support students throughout all aspects of the program was also emphasized. Department faculty followed up with those who attended virtual and in-person information sessions via phone calls, text messages, emails, video conferences, and face-to-face meetings. During these follow-up conversations, faculty emphasized how earning this degree and developing essential leadership skills would position prospective students to positively impact student success in significant ways. 
Recruitment efforts were successful. The first cohort consisted of 23 diverse and talented doctoral students. It is important to note that the size of the cohort exceeded expectations outlined in a demand study. The initial cohort size was almost three times the initial enrollment projections. Table 1 shows the program's success in recruiting a diverse cohort. Diversity in aspiring leaders is an important component of a program focused on activism and social justice.

Table 1. Cohort 1 Demographic Profile

\begin{tabular}{lrc}
\hline Demographic Characteristics & $\mathrm{n}$ & Percentage \\
\hline Gender & 17 & \\
Female & 6 & $74 \%$ \\
Male & & $26 \%$ \\
Professional Role & 13 & \\
$\quad$ Faculty (Full or part-time) & 8 & $56.5 \%$ \\
Administration/Staff & 2 & $34.5 \%$ \\
K-12 & & $9 \%$ \\
Ethnicity/Race & 1 & \\
Asian & 11 & $4 \%$ \\
Black & 3 & $48 \%$ \\
Hispanic & 8 & $13 \%$ \\
White & & $35 \%$ \\
\hline
\end{tabular}

\section{DEVELOPING A SAFE ATMOSPHERE TO EXPLORE SOCIAL JUSTICE ISSUES}

A key feature of the Capper et al.'s (2006) framework for preparing educational leaders for social justice is developing an atmosphere where students feel safe to explore complex and uncomfortable topics related to equity and social justice. Capper et al. noted:

For prospective leaders to fully engage with the curriculum, pedagogy, and assessment, professors must intentionally create a classroom and program environment and conditions, where students experience a sense of emotional safety that will help them take risks toward social justice ends. (p. 212)

This was and continues to be particularly important because of the diversity of the student population. Recognizing that students may come from backgrounds where their voices may not have been heard and safety was not a given, several actions were taken to develop a sense of safety and community. For example, faculty modeled the importance of talking about race and ethnicity by frequently bringing up equity issues in conversations and sharing personal and real-world examples.

\section{Admission Process}

Applicants participated in either an in-person or video conference interview with a committee comprised of three Educational Leadership faculty who reflected the diversity of the interviewees. From a traditional perspective, the development of an interview protocol that supports the selection of students who can articulate their preparation and motivation for doctoral study is a critical element in the admissions process. However, broadening the interview to include a discussion on current issues facing community colleges and asking candidates for suggestions on innovative approaches in meeting the challenge reinforced the activist expectation of the program. As part of the interview process, applicants were asked to write a three to five-page paper to respond to the following prompt: Describe an issue facing community colleges today. Using a social justice and equity lens, what are some innovative approaches to this challenge? Research has found that students who arrive with a commitment to and prior experiences with activism are more likely to engage in activism in the future (Dodd \& Mizrahi, 2017). This opportunity also served as a safe space for conversations about equity and social justice. The committee members validated applicant experiences and ideas and provided encouragement and support related to their goals and actions. Because feedback from applicants about the interview process was important as these processes were being implemented for the first time, a survey was conducted. Results indicated that applicants were satisfied with the interview process. Specifically, on a survey question that asked, "How satisfied were you with the Ed.D. in Community College interview process?", 19 of the 20 respondents indicated extremely satisfied and one indicated somewhat satisfied.

\section{On-boarding Process}

Students admitted to the program received an acceptance letter that communicated the faculty's belief in their ability to be a change agent. For example, the following was included in the letter: "We are confident that you will add significant value to the learning experience for the entire cohort and have no doubt that you will engage in leadership activities aimed at increasing student success outcomes for community college students." Messages of belief and encouragement continued to be shared with students throughout the program.

Students were invited to an in-person welcome reception and an online orientation program. Both activities were designed to begin 
the doctoral student socialization process and develop a community of learners where students felt safe to take risks and engage in courageous conversations about equity and social justice. During these events, faculty introduced students, highlighting their strengths and diverse backgrounds. Several colleagues at this event remarked that this approach, rather than relying exclusively on selfintroductions, communicated that faculty really knew their students well and genuinely valued their diverse backgrounds and experiences. Students also had opportunities to share preliminary research interests as well as to describe their professional goals and career aspiration. The efficacy of the onboarding programs was affirmed by student survey responses. Table 2 provides survey results related to the usefulness of the onboarding programs.

Table 2. On-Boarding Survey Responses

\begin{tabular}{ccc}
\hline Usefulness of the Program & $\begin{array}{c}\text { In-Person Welcome } \\
\text { Reception }(N=18)\end{array}$ & $\begin{array}{c}\text { Online Orientation } \\
(N=20)\end{array}$ \\
\hline Extremely useful & $78 \%$ & $70 \%$ \\
Very useful & $17 \%$ & $25 \%$ \\
Moderately useful & $6 \%$ & $5 \%$ \\
Slightly useful & $0 \%$ & $0 \%$ \\
Not at all useful & $0 \%$ & $0 \%$ \\
\hline
\end{tabular}

\section{Summer Institute}

This doctoral program is entirely online except for a 4-day institute each summer. One of the primary goals of the first summer institute was to build a sense of community and create a warm, supportive learning environment where students would be willing to get uncomfortable and take risks. Toward this end, doctoral students participated in several activities intentionally designed to help them get to know one another and begin conversations about problems of practice, especially problems related to equity and social justice. In addition to traditional icebreakers, students also had numerous opportunities to discuss issues facing community college students. For example, students explored the root causes of problems through fishbone diagram activities and brainstormed possible solutions. Fishbone diagrams are visual tools that groups can use to determine potential causes of behavior (American Society for Quality, 2020). Research has shown that this tool can be helpful in identifying solutions aimed to improve school quality (Slameto, 2016).

Students were also asked to do a Pecha Kucha presentation on a problem of practice and discuss the potential social justice impact. Pecha Kucha's are fast-paced, fun, structured presentations where the presenter's 20 slides auto-advance every 20 seconds (PechaKucha, 2020). Slides should only consist of an image and perhaps a few words. Research has shown that the Pecha Kucha presentation is connected to improved academic performance and confidence when compared to traditional presentations (Oliver \& Kowalczyk, 2013). Faculty modeled this practice on the first day of the institute and students presented on the final day of the institute.

Another key element of the summer institute was to ensure that students felt supported as they embarked on this educational journey. In addition to faculty support, students also learned about how other professionals such as tutors and librarians could support their learning. Faculty were and continue to be extremely accessible to students, providing support and encouragement. At the conclusion of the summer institute, students completed a survey about their experience. Results indicated that $100 \%$ of Cohort 1 (23 students) strongly agreed with the following statement: "The faculty members established a welcoming and inclusive learning environment."

\section{DEVELOPING CRITICAL CONSCIOUSNESS, KNOWLEDGE, AND SKILLS THROUGH SIGNATURE PEDAGOGIES}

To develop critical consciousness, knowledge, and skills, faculty relied on four key learning activities: the Community College Showcase, coursework, experiential learning, and the dissertation in practice. The Community College Showcase is a conference that is held during summer institutes. The coursework provides students with deep knowledge of community college leadership theories and scholarly practices. A year-long experiential learning component of the program enables students to learn leadership skills while providing a service to a community college. Finally, following CPED's guiding principles, the dissertation in practice is focused on providing solutions to problems of practice related to social justice and equity.

\section{Community College Showcase: Promoting Equity and Student Success}

To model and promote activism, faculty coordinators planned and implemented a conference entitled Community College Showcase: Promoting Equity and Student Success. This conference was purposefully called a showcase as the intent was for community college practitioners and leaders to share actions taken to reduce equity gaps and improve student success outcomes. Presenters were encouraged to share data illustrating the impact of these actions. The Community College Showcase was a signature pedagogical learning experience that was held on the second day of the summer institute. It was a free conference for professionals committed to the community college mission of access and success.

The level of activism taking place daily on community college campuses was immediately apparent. Over 70 high-quality proposals were received, a remarkable number for a first conference. The final program consisted of an impressive array of 23 breakout sessions 
and seven lunch discussions. The two plenary presentations were designed to inspire practitioners and leaders to act. In the morning plenary, Michael Collins, vice president at Jobs for the Future, encouraged all participants to lead, regardless of their position. In the closing plenary, Paula Pando, president of Reynolds Community College, emphasized the need for action to promote equity. See Table 3 for a sample of conference presentation topics.

The Community College Showcase provided doctoral students with an overview of the challenges facing community college students today, especially students from low-income backgrounds and students of color, and numerous models of how leaders were engaging in activism to reduce equity gaps and improve success outcomes. Doctoral students served as session moderators and participated in a special lunch session with the plenary speakers. After the conference, students were responsible for following up with participants to thank them for their participation and contributions. This provided students with a networking opportunity as this often led to continued conversations about student success and equity. Students also completed a reflective writing assignment that required them to consider how their actions can promote equity and success.

Table 3. Community College Showcase Sample Sessions

\begin{tabular}{ll}
\hline \multicolumn{1}{c}{ Presentation Type } & \multicolumn{1}{c}{ Presentation Title } \\
\hline Keynote Presentations & Next Generation Equity: Leading From Where You Are \\
& Taking Action to Promote Equity \\
Featured and Breakout Presentations & (Un)stable Identities: Diversity and Inclusion in the Community College Classroom \\
& A Conversation with Community College Leaders \\
& LGBTQI+ Programming in Urban Higher Education: \\
& Identifying and Confronting Community Tensions \\
& Surveying Inclusion and Equity Climate: Borough of Manhattan Community College's Use of \\
& Charrettes - Findings from Year One \\
& The Road to Equity in Education is Paved with Collaboration \\
& and Connection \\
& Strategies for Implementing Inclusion and Equity in the Community College Classroom \\
& First-generation Community College Students: Casting a Social Safety Net to Ensure Success \\
& Open the Gate: Accelerated Learning for Underserved Nontraditional Learners \\
& Underrepresented STEM Majors
\end{tabular}

The Community College Showcase also served professionals within the community college sector. Community college practitioners and leaders often have very limited funds for professional development and there are few conferences focused exclusively on how to better serve community college students. This free conference enabled over 200 faculty, staff, and administrators from numerous states to learn from and collaborate with national and local leaders.

Results from the conference survey indicated that the conference participants found the experience valuable. Based on survey responses from 80 participants, $70 \%$ were extremely satisfied and $26 \%$ were somewhat satisfied. Ninety-eight percent indicated that they would recommend the conference to a colleague. Analysis of the open-ended comments revealed that participants left inspired to act. The following responses are examples of how this conference promoted activism:

- It was a great conference. It has kickstarted some radical thinking on our campus.

- This was a great opportunity to hear about the status of equity in the community college setting. The workshops provided some good inspiration for ideas and programs to bring back to our home institutions.

- There were a number of diverse sessions that appealed to all community college stakeholders (from academic affairs, faculty, and student affairs). I always enjoy it when I am able to meet colleagues from other schools to share ideas and learn from one another. It is always great to hear about the successes and the failures that have occurred which serve as a catalyst to interesting conversations. Furthermore, it allows us as professionals to reboot ourselves or get refreshed and get excited (again) on why we do what we do.

- The conference allowed me to self-reflect on the work that we are doing in my own college and see how we can better our efforts. It was definitely a call to arms to continue along the path we have decided to approach and continue to advocate for our students and community. I was inspired.

Cohort 1 doctoral students also left inspired. The following are sample comments from a survey conducted at the end of the summer institute:

- So far, I am engaged and inspired to reach heights that I have never thought of before.

- $\quad$ The CC Showcase was an excellent learning experience that has energized me and transformed my thinking and overall goals.

- $\quad$ The CC Showcase was a wonderful experience that opened my eyes to the executive level of community college leadership that I had not even known existed. It was informative and allowed for networking with 
high-level leaders. I would have normally never had an opportunity like this.

\section{Coursework}

Identifying courses that promoted activism was an important part of the program design and development. The CPED (n.d.) guiding principles and design concepts served as a useful guide during this process. See Table 4 for a list of courses in the Ed.D. in Community College Leadership.

Table 4. Ed.D. in Community College Leadership Program Course Requirements

\begin{tabular}{|c|c|c|}
\hline Core Courses & Experiential Learning Courses & $\begin{array}{l}\text { Research and Dissertation } \\
\text { Courses }\end{array}$ \\
\hline Community Colleges: Past, Present, and Future & $\begin{array}{l}\text { Community College Leadership } \\
\text { Institute }\end{array}$ & The Scholarly Practitioner \\
\hline Leadership Theory and Change Management & Mentoring I & Educational Research I \\
\hline $\begin{array}{l}\text { Promoting Equity: Teaching and Supporting } \\
\text { Diverse Adult Learners }\end{array}$ & Experiential Learning I & Educational Research II \\
\hline Innovative Teaching Practices and Modalities & Experiential Learning II & Dissertation in Practice I \\
\hline Strategic Human Resource Management & Mentoring II & Dissertation in Practice II \\
\hline Curricular and Instructional Leadership & & Dissertation in Practice III \\
\hline \multicolumn{3}{|l|}{ Strategic Planning, Assessment, and Innovation } \\
\hline \multicolumn{3}{|l|}{ Student Services Leadership } \\
\hline \multicolumn{3}{|l|}{ Community College Finance } \\
\hline \multicolumn{3}{|l|}{$\begin{array}{l}\text { Critical Role of Partnerships in Community College } \\
\text { Leadership }\end{array}$} \\
\hline $\begin{array}{l}\text { Legal Issues, Policies, and Ethical Practices in the } \\
\text { Community College }\end{array}$ & & \\
\hline
\end{tabular}

Exposing practitioners to broader policy issues can increase empathy which can, in turn, lead to increased activism (Bicower, 2012). Toward this end, faculty invited national leaders and community college experts to communicate the sense of urgency for action and the challenges facing community colleges today through numerous synchronous meetings with doctoral students. In addition, faculty provided thought-provoking readings on community college topics that were discussed in the small and large group online forums.

Dodd and Mizrahi (2017) noted that activism can be reinforced through class activities. In the first course entitled Community Colleges: Past, Present, and Future, students were asked to write a paper from the historical lens of an underserved population. Bicower (2012) argued that it is important for students to "develop a political analysis of oppression" in order to become an activist (p. 573). This assignment provided students with the opportunity to explore how well community colleges have been fulfilling their access and success mission from the perspective of people of color, females, students with disabilities, and other underrepresented groups. After students completed this assignment, they then participated in an online discussion where they read the papers submitted by classmates and discussed the history of community colleges through these varied perspectives.

Another example of activism in coursework comes from the Leadership Theory and Change Management course. Students worked collaboratively with their peers to respond to case studies that highlighted the challenges encountered by students of color. In The Scholarly Practitioner class, students conducted four empathy interviews with students and professionals in the field to better understand problems of practices from various perspectives. Gallagher and Thordarson (2018) emphasized the importance of gaining the perspective of those experiencing problems or challenges. These assignment examples, along with regular reflection activities, illustrate how this program is helping students develop critical consciousness as described by Capper et al. (2006).

To help students develop essential knowledge and skills needed to be an effective community college leader, faculty required students to engage in several actions. One action was required tutoring. At the community college level, there is a national push to require students to participate in highly effective practices such as advising and tutoring, because the students who need the services the most are often the ones who are least likely to use the services (Mangan, 2013; Rendôn, 2006). Embedded tutoring has been shown to increase student success rates at the undergraduate level (The Community College League of California, 2017).

Because writing challenges have been cited by many colleagues at CPED convenings, during the first summer course, Community Colleges: Past, Present, and Future; all students were required to write a historical perspectives paper and then review this paper with a professional tutor prior to submitting the assignment. 
This provided a way to support all students, especially those who most needed the support without sending messages that could be interpreted as a lack of belief in their ability. Instead, it was framed as a supportive intervention for all. Reflection responses to this experience illustrated the value of this activity. Many students commented that they probably would not have used tutoring if not required to do so and that this was a helpful and supportive component of the class. When students see the value in a resource, they are more likely to use it (Nilsen, 2009). Faculty also supported students through reviewing draft submissions and providing robust, comprehensive feedback on assignments. Students were given opportunities to revise and resubmit their work. This practice emphasizes that learning is a process that takes time and continued effort.

Public scholarship, which can be defined as sharing research and best practices in accessible ways to broad audiences, has also been emphasized (Kezar, Drivalas, \& Kitchen, 2018). Most, if not all, courses will provide students with numerous opportunities to develop public scholarship documents such as blogs, policy briefs, and infographics. Engaging in public scholarship can also be considered a form of activism (Kezar et al., 2018). Public scholarship is particularly useful to community college practitioners who may not have the time or other resources to stay abreast of evidence-based practices. Delivering research-based content in brief formats that are easy to understand can increase the likelihood that community college practitioners and leaders will make data-informed decisions related to equity and success.

\section{Experiential Learning}

A year-long experiential learning component will take place in the second year of the program. This is another signature pedagogical learning experience. A service-learning approach will be used. Service-learning is defined as learning experiences, projects or placements that enable students to engage in tasks aligned to the learning outcomes of the course or program while benefitting the community (Prentice, 2007). In other words, students provide a service to a community organization as part of their overall learning experience and learn relevant skills while doing so. Research has shown a connection between student participation in service-learning and civic engagement, suggesting that service-learning is an excellent way to increase activism (e.g., Prentice, 2007).

Community college partners will identify areas where assistance is needed, and students will be matched to colleges based on their interests and career goals. This year, a pilot is underway where two students are providing consulting services to a local community college that is launching a new Teaching and Learning Center. The doctoral students meet with the director of this newly established center to provide guidance and support. The doctoral students have an external mentor who is providing 20 hours of individualized support. During this experience, it is expected that students will develop change management skills that will positively impact student success and reduce equity gaps. This signature learning experience also provides a benefit to community college partners who often do not have funding to bring in outside consultants. Having an external perspective often adds significant value to conversations focused on student success and equity. Doctoral students will also develop resources and curate related content for their community college partners.

\section{Dissertation in Practice}

Following the CPED framework, dissertations in this doctoral program need to focus on implementing and assessing solutions related to identified problems of practice. A program evaluation framework for the dissertation is being used. After investigating a problem of practice, students will need to implement a program, policy, or practice to address this problem and then conduct a program evaluation to determine if the intervention was effective. In some cases, students may conduct a program evaluation of an already existing program. Being a part of the CPED consortium from the design stage has been advantageous. Well-established programs can find it difficult to shift long-established expectations related to the dissertation. For example, Peterson (2017) noted that it can be challenging to incorporate practitioner-focused methods such as improvement science into traditional research sequences. As a new program, faculty were able to shift from traditional quantitative and qualitative courses to Educational Research I and Educational Research II. In these courses, quantitative and qualitative methods that support the program evaluation dissertation framework will be emphasized.

Engaging in research that is grounded in the scholarly practitioner framework through a program evaluation dissertation enables doctoral students to use research as a form of activism. Data on which practices are most effective at reducing equity gaps and improving student success is an important part of championing change. It is also critical that data is communicated to practitioners so that evidence-based decisions can be made. In addition to engaging in academic writing, doctoral students are also required to share the results of their dissertation via infographics, executive summaries, or other public-facing documents. Kezar et al. (2018) emphasized the importance of scholarly practitioners sharing their findings in accessible formats and platforms for a wide audience in order to have the greatest impact on student success.

Although the formal dissertation course sequence does not begin until the spring semester of the second year, students began the dissertation journey at the start of the program. At the first summer institute, students explored the root causes of problems of practice through fishbone diagrams and further explored their problem of practice through empathy interviews and a literature review in the fall semester during The Scholarly Practitioner course. At the end of this course, students were required to submit a blog summarizing what they learned along with a dissertation action plan. An essential part of this plan was for students to identify opportunities for activism related to their problem of practice. Opportunities for activism is defined as strategies or interventions that could be implemented to address their identified problem of practice. Students were asked the following questions to guide their research contribution to the field:

- What problem or issue do practitioners in the field need assistance with addressing?

- What are the root causes of this problem?

- What are the opportunities for activism related to this problem?

- What solution-focused interventions are within your sphere of influence?

- What is the potential impact of these interventions in terms of social justice and equity?

Thus, the research component of the program is also heavily emphasizing activism. It is hoped that the combination of 
conferences, coursework, experiential learning, and research will provide graduates with the knowledge, skills, and confidence needed to be transformational leaders who tirelessly engage in actions to improve student success outcomes and reduce equity gaps.

\section{RECOMMENDATIONS}

Faculty who want to launch or re-imagine a doctoral program with activism in mind can benefit from a framework and network. The guiding principles and network provided by CPED are an excellent start, but discipline-specific frameworks and partners can also add value. In this example, the AACC core competencies and an advisory board comprised of community college leaders were critical factors. Although the curriculum is often the focus of design or redesign efforts, faculty and coordinators will also want to consider how activism can be emphasized during the marketing, recruiting admission, and onboarding stages. Creating a sense of urgency around social justice and equity issues in pre-admission processes can motivate and inspire prospective students. Messaging that communicates the value of diversity and the need for leaders who reflect the student populations whom they serve can help programs attract a group of talented, diverse students.

Supporting students as they develop essential skills, such as the example of a required tutoring session, demonstrates a belief in and commitment to aspiring leaders. Emphasizing public scholarship and providing students with opportunities to develop these skillsets through assignments such as powerful readings, blogs, and infographics can help doctoral students discover the importance of activism and develop the confidence needed to act. Explicitly communicating the various forms of activism demonstrates to students how they will be able to use the research and other practical skills they are developing in the program to address social justice and equity issues.

\section{CONCLUSION}

The launching of this doctoral program with activism in mind was guided by Capper et al.'s (2006) framework for preparing leaders for social justice, CPED's guiding principles, and the AACC's (2018) competencies for community college leaders. Messages about the importance of equity and social justice were emphasized during marketing and recruitment efforts and reinforced through onboarding activities and coursework. These experiences combined with the experiential learning and dissertation components of the program will help students develop the skillsets needed to be an activist so that they are ready to lead efforts aimed at improving success rates and reducing equity gaps.

It is important to note that challenges were encountered along the way. Although launching a program with only two full-time faculty members made it possible to make decisions and enact changes swiftly, designing and launching a program simultaneously with a faculty of two was taxing. Fortunately, the university provided coordinator release time so that faculty attention was focused solely on the program. The advisory board has been and continues to be extremely gracious with their time and this has been tremendously valuable. Having thought partners for this work, especially partners who are practitioners in the field, enabled the faculty to identify ways to promote activism throughout the program. In addition to capacity issues, another challenge was the lack of models or examples available. Faculty were open to ideas presented by CPED colleagues such as using a program evaluation framework for the dissertation but because change is much more difficult in established programs, models and resources were limited. Having individual conversations with CPED members and other professionals and faculty who share similar interests and goals have provided faculty with helpful guidance and support.

There is still much work to be done. Faculty are currently in the process of developing resources that map out the courses, experiential learning, and dissertation expectations. In addition, faculty are exploring ways to publicly share research and related information that can inspire activism along with examples of activism by current students and faculty. Toward this end, a department Linkedln page was developed and will be used to showcase the accomplishments of students and faculty, especially as they relate to improving success and reducing equity gaps. As courses are being designed, faculty will continue to use the framework and guiding principles outlined in this article to identify learning tasks and assignments that will inspire students to engage in activism and equip them with the skills to do so. It will also be important to develop an assessment plan that goes beyond traditional success measures and also measures activism.

\section{REFERENCES}

Allen, J. G., Wasicsko, M., \& Wirtz, P. J. (2018). Using dispositions in the EdD admissions process: A perceptual approach. Impacting Education: Journal on Transforming Professional Practice, 3(2), 1-10.

American Association of Community Colleges (AACC). (AACC2018). AACC competencies for community college leaders. $3^{\text {rd }}$ edition. Retrieved from: https://www.aacc.nche.edu/wp-

content/uploads/2018/11/AACC2018Competencies_111618_FINAL.pdf

American Society for Quality. (2020). Fishbone diagram. Retrieved from: https://asq.org/quality-resources/fishbone

Bicower, B. (2012). Teacher activism: Enacting a vision for social justice. Equity and Excellence in Education, 45(4), 561-574.

Capper, C. A., Theoharis, G., \& Sebastian, J. (2006). Toward a framework for preparing leaders for social justice. Journal of Educational Administration, 44(3), 209-224.

Carnegie Project on the Education Doctorate (CPED) (n.d.). The CPED framework. Retrieved from: https://cped.memberclicks.net/the-framework

Dodd, S. J., \& Mizrahi, T. (2017). Activism before and after graduate education: Perspectives from three cohorts of MSW students. Journal of Social Work Education, 53(3), 503-519.

Gallagher, A., \& Thordarson, K. (2018). Design thinking for school leaders: Five roles and mindsets that ignite positive change. ASCD.

George, P. (2017). Toward a social justice model for an EdD program in higher education. Impacting Education: Journal on Transforming Professional Practice, 2(1), 41-52.

Kezar, A., Drivalas, Y., \& Kitchen, J. A. (2018). Envisioning public scholarship for our time: Models for higher education researchers. Stylus Publishing: Sterling, VA.

Mangan, K. (2013, October 25). Tactics that engage community-college students get few takers, study finds. Chronicle of Higher Education, $60(8), 12$.

Nilsen, H. (2009). Influence on student academic behaviour through motivation, self-efficacy and value-expectation: An action research project to improve learning. Issues in Informing Science and Information Technology, 6, 1-12.

Oliver, J., \& Kowalczyk, C. (2013). Improving student group marketing presentations: A modified Pecha Kucha approach. Marketing Education Review, 23(1), 55-58.

PechaKucha. (2020). Visual storytelling that celebrates humanity. Retrieved from https://www.pechakucha.com/ 
Peterson, D. S. (2017). Preparing scholarly practitioners: Redesigning the EdD to reflect CPED principles. Impacting Education: Journal on Transforming Professional Practice, 2(1), 33-40.

Prentice, M. (2007). Service-learning and civic engagement. Academic Questions, 20(2), 135-145.

Rendôn, L. I. (2006). Reconceptualizing success for underserved students in higher education. National Postsecondary Education Cooperative. https://nces.ed.gov/npec/pdf/resp_Rendon.pdf

Slameto. (2016). The application of fishbone diagram analysis to improve school quality. Dinamika IImu Journal of Education, 16(1), 59-74.

The Community College League of California (2017, September). Elevating equity for social mobility: Examples of equity-focused practices.

https://www.ccleague.org/sites/default/files/images/elevatingequityforsoci almobility_final.pdf 